\title{
Classification of Pseudomonas aminovorans and Some Related Methylated Amine Utilizing Bacteria
}

\author{
By P. N. GREEN ${ }^{1 *}$ AND M. GILLIS ${ }^{2}$ \\ ${ }^{1}$ NCIMB Ltd, PO Box 31, 135 Abbey Road, Aberdeen AB9 8DG, UK \\ ${ }^{2}$ Laboratorium voor Microbiologie en Microbiële Genetica, Rijksuniversiteit, \\ B-9000 Gent, Belgium
}

(Received 13 February 1989; revised 10 April 1989; accepted 17 April 1989)

Eight strains of facultatively methylotrophic budding bacteria which utilized mono- and trimethylamine as sole carbon and energy source were shown to belong to the AgrobacteriumRhizobium complex in rRNA superfamily IV. It is considered that these organisms probably represent a new taxon; a description is provided, and the taxonomy is discussed.

\section{INTRODUCTION}

Facultatively methylotrophic bacteria are organisms which can utilize either one-carbon or multi-carbon compounds as sole carbon and energy source. They include a diverse assemblage of organisms (Green \& Bousfield, 1981), some of which fit into well recognized taxa. Others, such as the pink-pigmented facultative methylotrophs, have been shown to constitute a new taxon, for which the genus Methylobacterium was subsequently proposed (Patt et al., 1974; Green \& Bousfield, 1983).

In 1982, seven strains of non-pigmented, motile, Gram-negative bacteria, which could utilize mono- and trimethylamine but could not utilize methanol, were examined as part of a numerical taxonomic study of some Gram-negative facultatively methylotrophic bacteria. They were shown to form a fairly tight cluster (cluster 1 ; approx $90 \%$ similarity level), well separated from the other methylotrophic bacteria and non-methylotrophic reference strains examined (Green \& Bousfield, 1982). Since that study it has become apparent that Pseudomonas aminovorans (NCIB 9039), a similar methylated amine utilizing organism, isolated by den Dooren de Jong (1927) from soil, is phenotypically and morphologically indistinguishable from the seven isolates previously examined (P. N. Green, unpublished data).

These organisms including $P$. aminovorans, reproduce by budding (L. B. Perry, unpublished observation), suggesting a link between these facultatively methylotrophic bacteria, and other taxa which exhibit budding or polar growth. Various members of the ribosomal ribonucleic acid (rRNA) superfamily IV sensu De Ley (1978), reproduce by budding division (L. B. Perry, personal communication), and the reference strain of $P$. aminovorans has already been allocated to the Rhizobium-Agrobacterium complex of this rRNA superfamily (De Ley et al., 1987). It was therefore important to examine the facultative methylotrophs in light of the above findings.

\section{METHODS}

Bacterial strains and growth media. The following seven organisms were examined: Pseudomonas aminovorans NCIB 9039 (den Dooren de Jong, 1927); Pseudomonas MA, NCIB 11590 (Shaw et al., 1966); Pseudomonas MS, NCIB 11591 (Wagner, 1964); strain 5H2, NCIB 11347 (Hampton \& Zatman, 1973) and strains 27, 32,36 and 44 isolated by A. J. Smith, University College of Wales, Aberystwyth. Cultures were grown and maintained on Bennett's agar (Keeble \& Cross, 1977). Stock cultures were incubated at $25^{\circ} \mathrm{C}$ and sub-cultured every $14 \mathrm{~d}$.

Characterization of strains. Most of the methods used for physiological and biochemical characterization, utilization of substrates as sole carbon source and DNA base ratios $(\mathrm{mol} \% \mathrm{G}+\mathrm{C})$, were as described by Green \& Bousfield (1982). Exceptions included utilization of ferulic, coumaric and anisic acids, and oligotrophic growth, 
which were tested by the methods of Ohta \& Hattori (1983). The ability of bacteria to grow autotrophically was examined in an atmosphere of $\mathrm{H}_{2} / \mathrm{CO}_{2} / \mathrm{O}_{2}(75: 15: 10)$ on the medium described by Aragno \& Schlegel (1981). Media and procedures for the detection of acid from yeast mannitol agar (YMA) containing bromothymol blue and from glucose-peptone agar containing bromocresol purple, absorption of Congo red on YMA-Congo red agar plates, reduction of Nile blue, precipitate formation in calcium glycerophosphate agar, and growth in the presence of $2 \%(\mathrm{w} / \mathrm{v}) \mathrm{NaCl}$ were as described by Vincent et al. (1979).

Morphological studies. These were performed by phase-contrast microscopy, using exponentially growing broth cultures immobilized on both pre-dried plates of Bennett's agar and on Cytophaga agar (Anaker \& Ordal, 1959) containing $1.5 \%(\mathrm{w} / \mathrm{v})$ agar (Difco), over a period from $1 \mathrm{~h}$ to several days at room temperature using a Zeiss photomicroscope.

Ribosomal ribonucleic acid homologies. Methods for the extraction and preparation of high- $M_{\mathrm{r}}$ DNA, labelled rRNA and the hybridization procedures used were as described by De Ley et al. (1987). The following labelled rRNAs were used: 23S [ $\left.{ }^{3} \mathrm{H}\right]$ rRNA from Rhizobium loti NZP 2037, Rhizobium meliloti NZP 4009 (Jarvis et al., 1986) and Brucella abortus ATCC $23488^{\mathrm{T}}$ (De Ley et al., 1987), and 23S $\left[{ }^{14} \mathrm{C}\right] \mathrm{rRNA}$ from Agrobacterium tumefaciens ICPB TT111 (De Smedt \& De Ley, 1977) and Bradyrhizobium japonicum NZP 5549T (Jarvis et al., 1986).

\section{RESULTS AND DISCUSSION}

\section{Morphological and physiological properties}

All of the facultative amine-utilizing bacteria discussed in this paper (the 'aminovorans' taxon) conformed to the following description. They were Gram-negative rods $(0.6-0.8 \times 1.0-2.5 \mu \mathrm{m})$, sometimes pleomorphic, bent or branched. Reproduction occurred by budding. This usually took the form of polar growth, but occasionally lateral budding or branching was seen (Fig. 1). No stalks, prosthecae or other holdfast structures were present. The cells were motile, with single or multiple polar, sub-polar or lateral flagella. Colonies on nutrient agar were off-white and slow-growing $\left(1-2 \mathrm{~mm}\right.$ in $7 \mathrm{~d}$ at $\left.25^{\circ} \mathrm{C}\right)$; they did not form extracellular polysaccharide slimes on carbohydrate-containing media. Older colonies ( $>7 \mathrm{~d}$ ) had a pale brown centre. The cultures were obligately aerobic, and chemoorganotrophic. They did not grow oligocarbophilically or autotrophically; did not fix atmospheric nitrogen and, as far as is known, do not form nitrogenfixing symbiotic relationships with plants. They grew at $5^{\circ} \mathrm{C}$ and $30^{\circ} \mathrm{C}$, but not at $37^{\circ} \mathrm{C}$; the optimum grown temperature was about $25^{\circ} \mathrm{C}$. Oxidase and catalase were present.

The following carbon sources were utilized by all strains: D-xylose, D-rhamnose, D-glucose, D-mannose, D-galactose, D-fructose, sucrose, trehalose, maltose, cellobiose, inositol, glycerol, sorbitol, mannitol, lactate, acetate, propionate, pyruvate, DL-arginine, L-alanine, L-valine, monomethylamine, trimethylamine, trimethylamine- $N$-oxide and glucosamine. Some strains utilized L-arabinose, D-fucose, L-glutamate, citraconate, L-leucine, L-histidine, ethylamine,
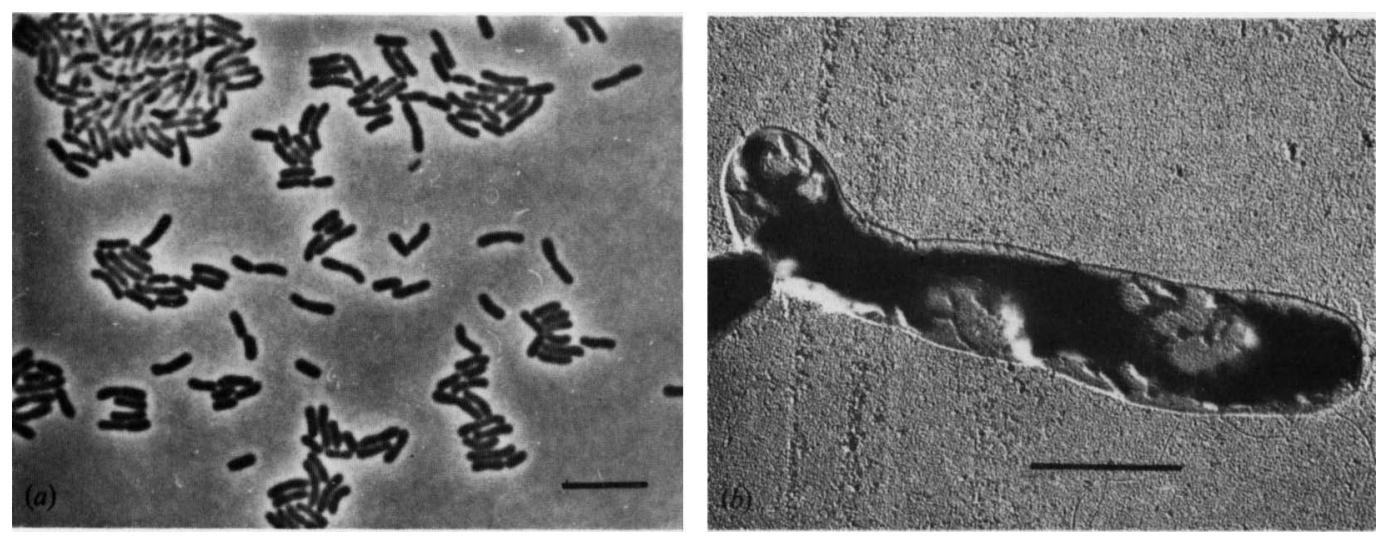

Fig. 1. (a) Photomicrograph, showing typical cellular morphology in a culture of Pseudomonas aminovorans grown on cytophaga agar after about $4 \mathrm{~h}$ incubation at $25^{\circ} \mathrm{C}$, Bar, $5 \mu \mathrm{m}$. (b) Electron micrograph showing polar growth in a member of the 'aminovorans' taxon. Bar, $1 \mu \mathrm{m}$. 
Table 1. DNA base composition, and properties of the DNA :rRNA hybridizations carried out

\begin{tabular}{|c|c|c|c|c|c|c|c|c|c|c|c|}
\hline & & & & rces & abelled & RNA & eference & strail & & & \\
\hline & & $\begin{array}{l}\text { Rhi } \\
\text { NZ }\end{array}$ & $\begin{array}{l}\text { obium } \\
\text { oti } \\
\text { P } 2037\end{array}$ & $\begin{array}{r}R h \\
m \\
\text { NZ }\end{array}$ & $\begin{array}{l}\text { zobium } \\
\text { eliloti } \\
\text { P } 4009\end{array}$ & $\begin{array}{r}\text { Brad } \\
\text { jap } \\
\text { N2 }\end{array}$ & $\begin{array}{l}\text { hizobium } \\
\text { nicum } \\
\text { P } 5549\end{array}$ & $\begin{array}{l}\text { Agrol } \\
\text { tum } \\
\text { ICP }\end{array}$ & $\begin{array}{l}\text { acterium } \\
\text { efaciens } \\
\text { TT111 }\end{array}$ & $\begin{array}{r}B r \\
a b \\
\text { ATC }\end{array}$ & $\begin{array}{l}\text { ocella } \\
\text { ortus } \\
\text { C } 23448\end{array}$ \\
\hline Organism & $\begin{array}{l}\mathrm{Mol} \% \\
\mathrm{G}+\mathrm{C}+\end{array}$ & $\begin{array}{c}T_{\operatorname{m(e)}} \\
\left({ }^{\circ} \mathrm{C}\right)\end{array}$ & $\begin{array}{c}\text { rRNA } \\
\text { binding } \\
(\%)\end{array}$ & $\begin{array}{l}T_{\text {m(e) }} \\
\left({ }^{\circ} \mathrm{C}\right)\end{array}$ & $\begin{array}{c}\text { rRNA } \\
\text { binding } \\
(\%)\end{array}$ & $\begin{array}{l}T_{\text {m(e) }} \\
\left({ }^{\circ} \mathrm{C}\right)\end{array}$ & $\begin{array}{c}\text { rRNA } \\
\text { binding } \\
(\%)\end{array}$ & $\begin{array}{r}T_{\mathrm{m}(\mathrm{e})} \\
\left({ }^{\circ} \mathrm{C}\right)\end{array}$ & $\begin{array}{c}\text { rRNA } \\
\text { binding } \\
(\%)\end{array}$ & $\begin{array}{r}T_{\mathrm{m}(\mathrm{e})} \\
\left({ }^{\circ} \mathrm{C}\right)\end{array}$ & $\begin{array}{c}\text { rRNA } \\
\text { binding } \\
(\%)\end{array}$ \\
\hline P. aminovorans & & & & & & & & & & & \\
\hline NCIB 9039 & $61 \cdot 8$ & $76.7^{*}$ & $0.06^{*}$ & & & & & $72 \cdot 7^{*}$ & $0.08^{*}$ & $72 \cdot 5^{*}$ & $0.07^{*}$ \\
\hline $\begin{array}{r}\text { Pseudomonas } \\
\text { strain MA }\end{array}$ & 63.9 & $75 \cdot 5$ & 0.08 & $69 \cdot 9$ & 0.05 & $63 \cdot 4$ & $0 \cdot 07$ & & & & \\
\hline Pseudomonas & & & & & & & & & & & \\
\hline $\begin{array}{l}\text { strain MS } \\
\text { strain } 5 \mathrm{H} 2 \\
\text { strain } 27 \\
\text { strain } 32 \\
\text { strain } 36 \\
\text { strain } 44\end{array}$ & $\begin{array}{l}62 \cdot 5 \\
64 \cdot 5 \\
64 \cdot 7 \\
63 \cdot 2 \\
62 \cdot 5 \\
63 \cdot 7\end{array}$ & $77 \cdot 2$ & $0 \cdot 10$ & $72 \cdot 7$ & $0 \cdot 04$ & & & & & & \\
\hline $\begin{array}{l}\text { Blastobacter } \\
\text { denitrificans } \\
\text { NCIB } 12292\end{array}$ & $64 \cdot 5 t$ & $67 \cdot 0$ & 0.03 & $67 \cdot 6$ & 0.03 & $77 \cdot 0$ & 0.05 & & & & \\
\hline
\end{tabular}

*Taken from De Ley et al. (1987); $\quad$ †taken from Green (1981); $\quad \ddagger$ taken from Hirsch \& Muller (1985).

ethanolamine, butylamine and $p$-hydroxybenzoate. None of the following carbon sources were utilized: starch, erythritol, adonitol, malonate, succinate, fumarate, citrate, L-aspartate, adipate, sebacate, 2-oxoglutarate, DL-malate, D-tartrate, D-laevulinate, pelargonate, saccharate, DL-phenylalanine, ethanol, propylene glycol, 2,3-butylene glycol, geraniol, methanol, tryptamine, amylamine, histamine, putrescine, $m$-hydroxybenzoate, testosterone, sarcosine, phenol, ferulic acid, $p$-coumaric acid or $p$-anisic acid. All strains were sensitive to tetracyclines, penicillin, novobiocin, neomycin, vancomycin, gentamicin, carbenicillin, albamycin $T$ and framycetin, but resistant to streptomycin.

Most strains grew at $\mathrm{pH} 4.5$ and 9.5 and all strains grew moderately slowly (colony diameter 1-2 mm, $7 \mathrm{~d}, 25^{\circ} \mathrm{C}$ ) on Bennett's agar, nutrient agar (Oxoid CM3) and yeast mannitol agar (YMA). Weak to moderate acidity was produced in YMA plus bromothymol blue and glucose peptone agar containing bromocresol purple. Congo red was weakly absorbed when cultures were grown on YMA-congo red agar plates. All strains grew in yeast mannitol broth in the presence of $2 \%(\mathrm{w} / \mathrm{v}) \mathrm{NaCl}$, but grew poorly and produced no change in litmus milk. They did not reduce Nile blue. Casein, cellulose, gelatin, lecithin, starch and DNA were not degraded. Urease was produced and some strains produced a precipitate in calcium glycerophosphate agar, but 3-ketolactose, $\beta$-galactosidase, indole, $\mathrm{H}_{2} \mathrm{~S}$, L-ornithine and L-lysine decarboxylases and $\mathrm{L}$-arginine dihydrolase were not produced. The methyl red and Voges-Proskauer tests were negative. Some strains reduced nitrate to nitrite. Acetylene reduction was not detected (D. C. Jordan, personal communication), and representative strains failed to induce root nodule formation on the following plant species: Medicago sativa, Trifolium repens, Pisum sativum, Phaseolus vulgaris, Lupinus sp., Glycine ussuriensis and Vigna mungo (M. Dye, personal communication).

The guanine plus cytosine content of the DNA ranged from 61.8 to $64.7 \mathrm{~mol} \%$ (Green \& Bousfield, 1982).

We suggest that NCIB 9039 (Pseudomonas aminovorans), which was the original strain (Den Dooren de Jong, 1927) isolated from garden soil, is a suitable representative strain. 


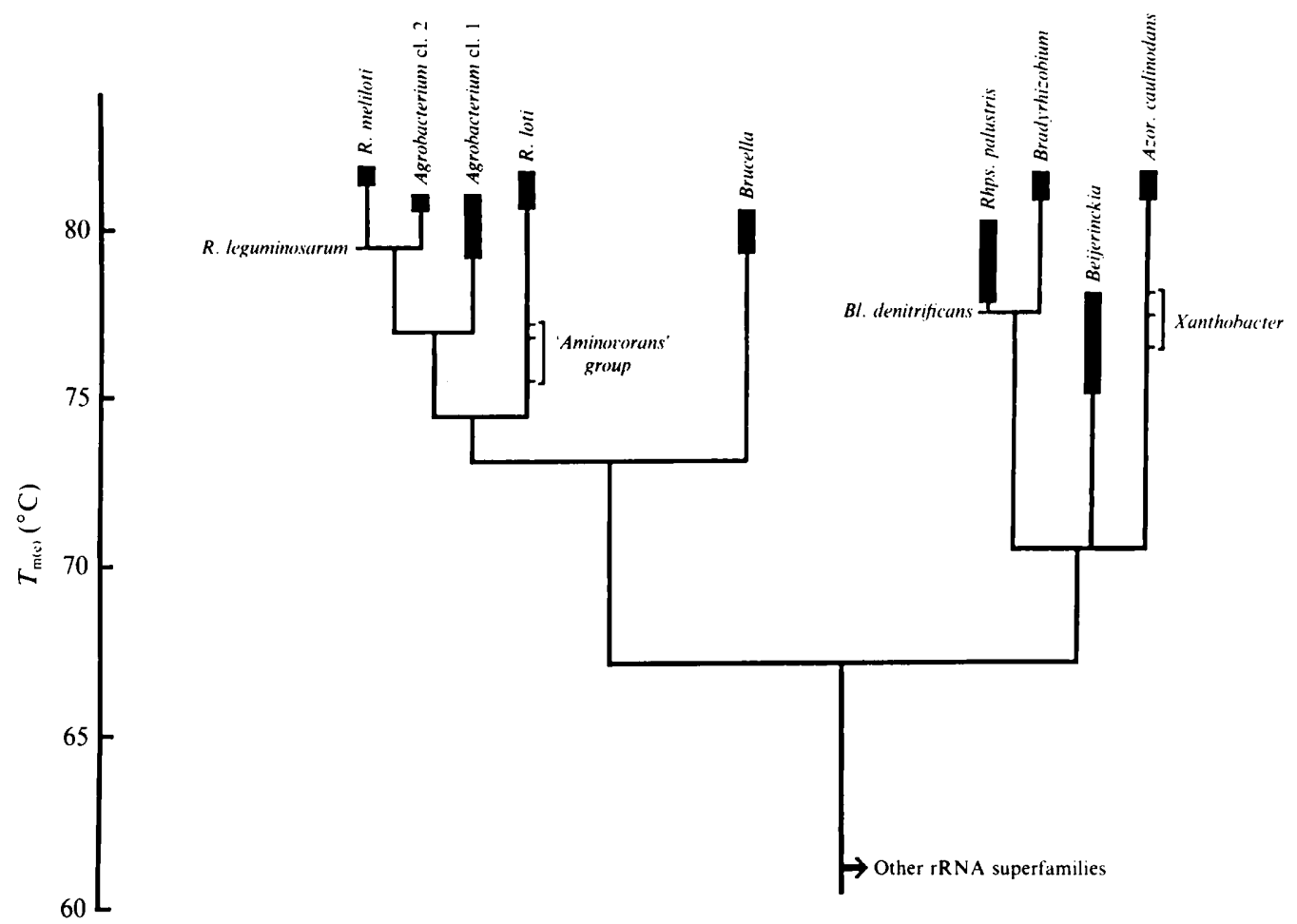

Fig. 2. Simplified rRNA cistron similarity dendrogram of part of rRNA superfamily IV, based on $T_{\mathrm{m}(e)}$ values of DNA :rRNA hybrids (see Jarvis et al., 1986). R., Rhizobium; cl, cluster; Rhps., Rhodopseudomonas; Azor., Azorhizobium; Bl., Blastobacter.

\section{Nucleic acid analyses}

The average percentage $\mathrm{G}+\mathrm{C}$ values of the eight strains are given in Table 1 . The DNArRNA hybridization data are also shown in Table 1, and are represented diagramatically in Fig. 2; where the relationship of the 'aminovorans' taxon is illustrated in relation to other members of rRNA superfamily IV.

These results show that Pseudomonas MA and Pseudomonas MS, two representative strains from the group of phenotypically similar methylated amine utilizing bacteria studied earlier by Green \& Bousfield (1982), do indeed cluster together with the type strain of $P$. aminovorans in rRNA superfamily IV. With $T_{\mathrm{m}(\mathrm{e})}$ values from $75.5^{\circ} \mathrm{C}$ to $77.2^{\circ} \mathrm{C}$ versus $23 \mathrm{~S}\left[{ }^{3} \mathrm{H}\right] \mathrm{rRNA}$ of Rhizobium loti NZP 2037, they belong to the Rhizobium loti rRNA branch, which is the most remote taxon in the Agrobacterium-Rhizobium rRNA complex (Jarvis et al., 1986).

However, the $T_{\mathrm{m}(\mathrm{e})}$ values (about $5{ }^{\circ} \mathrm{C}$ difference between $R$. loti and the facultatively methylotrophic 'aminovorans' taxon) suggest that the latter does not belong to $R$. loti. This is further substantiated by phenotypic evidence. $R$. lot $i$, like most of the fast-growing rhizobia, produce fairly large (3-4 mm diam.) mucoid colonies on yeast mannitol agar after $3-5 \mathrm{~d}$ at $25^{\circ} \mathrm{C}$, whereas strains within the 'aminovorans' taxon produce smaller (1-2 mm diam.) non-mucoid colonies. Also, representative strains of the 'aminovorans' taxon do not exhibit acetylene reduction in pure culture (D. C. Jordan, personal communication).

Based on previous phenotypic studies, the eight strains discussed in this paper could be closely related to the genus Blastobacter, which contains heterotrophic rod-shaped budding bacteria that do not fix nitrogen. Although seven species of the genus Blastobacter have been described, a number of these, including the type species, $B$. henricii, are not available for comparative purposes. Recent work by Stackebrandt and his colleagues (Rothe et al., 1987), using 16S ribosomal RNA cataloguing, have shown that the type strain of Blastobacter aggregatus also 
belongs to the alpha sub-class of the Proteobacteria (and by implication rRNA superfamily IV). These workers found B. aggregatus to be more closely related $\left(S_{\mathrm{AB}}=0.84\right)$ to Agrobacterium tumefaciens DSM 30150 (= ATCC 4720), an organism which is a member of Agrobacterium cluster 1 (De Smedt \& De Ley, 1977), than to Rhizobium leguminosarum ATCC 10004. Agrobacterium cluster 1 and $R$. leguminosarum, both of which are members of rRNA superfamily IV, are shown in Fig. 2.

Unfortunately, Rothe et al. (1987) did not include Rhizobium loti, on which rRNA branch the 'aminovorans' taxon clusters, in their study. However, it is clear from Fig. 2 that $R$. loti, and hence the 'aminovorans' taxon, is even further removed from Agrobacterium cluster 1 than $R$. leguminosarum, and thus cannot be closely related to $B$. aggregatus.

In addition Blastobacter denitrificans (Hirsch \& Muller, 1985), a facultative methanol utilizer, has been shown to have a $T_{\mathrm{m}(\mathrm{e})}$ value of $67.0^{\circ} \mathrm{C}$ versus $23 \mathrm{~S}\left[{ }^{3} \mathrm{H}\right] \mathrm{rRNA}$ of $R$. loti NZP 2037 (see Table 1), thus indicating its distant relationship to that species, and, by implication, to the 'aminovorans' taxon. Indeed, its close association with the Bradyrhizobium japonicumRhodopseudomonas palustris rRNA branch of superfamily IV is testimony to the heterogeneity within the genus Blastobacter.

As a consequence of these findings and the unavailability of several Blastobacter species for comparative purposes, the present authors do not consider it prudent to make formal taxonomic proposals at present. We also propose that until the internal homogeneity of the 'aminovorans' taxon is examined in more detail, that all the strains described in this paper be considered as belonging to a single species.

We acknowledge the helpful discussions with L. B. Perry, and thank D. C. Jordan, University of Guelph, USA, and M. Dye, Rothamsted Experimental Station, Harpenden, who tested cultures for nitrogen fixation and plant nodulation respectively.

\section{REFERENCES}

ANAKer, R. L. \& ORdal, E. J. (1959). Studies on the myxobacterium Chondrococcus columnaris. Journal of Bacteriology 78, 25-32.

ARAGNo, M. \& SCHLEGEL, H. G. (1981). The hydrogenoxidizing bacteria. In The Prokaryotes, $A$ Handbook on Habitats, Isolation and Identification of Bacteria, pp. 865-893. Edited by M. P. Starr, H. Stolp, H. G. Trüper, A. Balows \& H. G. Schlegel. Berlin: Springer Verlag.

DE LEY, J. (1978). Modern molecular methods in bacterial taxonomy: evaluation, application prospects. In Proceedings of the 4th International Conference on Plant Pathogenic Bacteria, pp. 347-357. Edited by I.N.R.A. Angers. Tours: Gibert-Clarey.

De Ley, J., Mannheim, W., Segers, P., Lievens, A., Denyn, M., VanhoucKe, M. \& Gillis, M. (1987). Ribosomal ribonucleic acid cistron similarities and taxonomic neighborhood of Brucella and CDC Group Vd. International Journal of Systematic Bacteriology 37, 35-42.

DE SMEDT, J. \& DE LEY, J. (1977). Intra- and intergeneric similarities of Agrobacterium ribosomal ribonucleic acid cistrons. International Journal of Systematic Bacteriology, 27, 222-240.

DEN DOOREN DE JoNG, L. E. (1927). Uber protaminophage Bakterien. Zentralblatt fur Bakteriologie, Parasitenkunde, Infektionskrankheiten und Hygiene (Abteilung II) 71, 193-232.

GREEN, P. N. (1981). A taxonomic study of some facultatively methylotrophic bacteria. $\mathrm{PhD}$ thesis. Heriot-Watt University, Edinburgh.

GREEN, P. N. \& Bousfield, I. J. (1981). Taxonomy of pink-pigmented facultatively methylotrophic bacteria. In Microbial Growth on $C^{1}$ Compounds, pp. 285-293. Edited by H. Dalton. London: Heyden \& Son.

Green, P. N. \& Bousfield, I. J. (1982). A taxonomic study of some Gram-negative facultatively methylotrophic bacteria. Journal of General Microbiology 128 , 623-638.

GREEN, P. N. \& Bousfield, I. J. (1983). Emendation of Methylobacterium (Patt, Cole and Hanson 1976), Methylobacterium rhodinum (Heumann 1962) comb. nov. corrig., Methylobacterium radiotolerans (Ito and Iizuka 1971) comb. nov. corrig. and Methylobacterium mesophilicum (Austin and Goodfellow 1979) comb. nov. International Journal of Systematic Bacteriology 33, 875-877.

Hampton, D. \& Zatman, L. J. (1973). The metabolism of tetramethylammonium chloride by bacterium 5H2. Biochemical Society Transactions 1, 667.

HirsCh, P. \& MulleR, M. (1985). Blastobacter aggregatus sp. nov., Blastobacter capsulatus sp. nov., and Blastobacter denitrificans sp. nov., new budding bacteria from fresh water habitats. Systematic and Applied Microbiology 6, 281-286.

JARVIS, B. D. W., Gillis, M. \& DE LeY, J. (1986). Intra- and intergeneric similarities between the ribosomal ribonucleic acid cistrons of Rhizobium and Bradyrhizobium species and some related bacteria. International Journal of Systematic Bacteriology 36, 129-138.

Keeble, J. R. \& Cross, T. (1977). An improved medium for the enumeration of Chromobacterium in 
soil and water. Journal of Applied Bacteriology 43, 325-327.

OHTA, H. \& HatToRi, T. (1983). Agromonas oligotrophica gen. nov. sp. nov., a nitrogen-fixing oligotrophic bacterium. Antonie van Leeuwenhoek 49, 4429-4446.

Patt, T. E., Cole, G. C., Bland, J. \& Hanson, R. S. (1974). Isolation and characterization of bacteria that grow on methane and organic compounds as sole sources of carbon and energy. Journal of Bacteriology 120, 955-964.

Rothe, B., Fischer, A., Hirsch, P., Sittig, M. \& STACKEBRandT, E. (1987). The phylogenetic position of the budding bacteria Blastobacter aggregatus and
Gemmobacter aquatilis gen. nov. sp. nov. Archives of Microbiology 147, 92-99.

Shaw, W. V., Tsai, L. \& Stadtman, J. (1966). The enzymatic synthesis of $N$-methylglutamic acid. Journal of Biological Chemistry 241, 935-945.

Vincent, J. M., Nutman, P. S. \& Skinner, F. A. (1979). The identification and classification of Rhizobium. In Identification Methods for Microbiologists (Society for Applied Bacteriology Technical Series no. 14), pp. 49-69. Edited by F. A. Skinner \& D. W. Lovelock. London: Academic Press.

WAGNER, C. (1964). Growth and metabolism on a onecarbon compound: trimethylsulfonium chloride. Bacteriological Proceedings 64, 91. 